\title{
TREND OZLJEDA NA RADU U KARLOVAČKOJ ŽUPANIJI OD 2012. DO 2017. GODINE
}

SAŽETAK: Jedan od temeljnih pokazatelja razvoja sigurnosti i zaštite na radu u nekoj društvenoj odnosno socijalnoj sredini u promatranom razdoblju je broj evidentiranih profesionalnih bolesti te ozljeda na radu u tom razdoblju. Analizom javno objavljenih podataka o broju prijavljenih ozljeda na radu u razdoblju od 2012. do 2017. godine utvrđen je trend kretanja godišnjeg broja ozljeda na radu u Republici Hrvatskoj. Poseban osvrt dan je na očekivana kretanja broja ozljeda u Karlovačkoj županiji. Utvrđeni trend porasta godišnjeg broja ozljeda na radu pokazatelj je kriznog stanja sigurnosti i zaštite na radu kako u Karlovačkoj županiji tako i u cijeloj Republici Hrvatskoj te ukazuje na potrebu planiranja, educiranja, kontroliranja i provođenja odgovarajućih mjera sigurnosti na radu u svim segmentima društva.

Ključne riječi: ozljeda na radu, sigurnost na radu, statističke metode, trend

\section{UVOD}

Prevencija, kao jedan od osnovnih mehanizama za sprečavanje ozljeda na radu, profesionalnih i drugih bolesti u vezi s radom i zaštitom radnog okoliša, krajnji je cilj provedbe zaštite na radu utvrđen Zakonom o zaštiti na radu. Primjena razvijenog sustava upravljanja zaštitom zdravlja i sigurnosti na radu od temeljne je važnosti za smanjenje broja nesreća, bolesti i smrtnih slučajeva na radu. Značajni pokazatelj stanja i razvoja sigurnosti na radu u Republici Hrvatskoj je broj zaprimljenih prijava ozljeda na radu koje su ispunili poslodavci i dostavili Hrvatskom zavodu za zdravstveno osiguranje (HZZO). Na osnovi podataka prikupljenih od Državnog zavoda za statistiku (DZS) o broju zaposlenih po granama djelatnosti i podataka o broju ozljeda na radu prijavljenih HZZO-u, Hrvatski zavod za zaštitu zdravlja i sigurnosti na radu (HZZZSR) kontinuirano prati i analizira podatke o ozljedama na radu u skladu

*Mr. sc. Marina Tevčić, (marina.tevcic@vuka.hr), mr. sc. Snježana Kirin, (snjezana.kirin@vuka.hr), Veleučilište u Karlovcu, J. J. Strossmayera 9, 47000 Karlovac. s metodologijom Europske statistike ozljeda na radu (ESAW metodologija) te svake godine izdaje cjelovito izvješće Analiza ozljeda na radu za prethodnu godinu. Izvješće se javno objavljuje na internetskoj stranici www.hzzzsr.hr. Uz godišnje izvješće, HZZZSR izračunava i objavljuje i stopu ozljeda na radu na 1000 zaposlenih radnika za prethodnu godinu.

U ovome radu, na osnovi objavljenih podataka u razdoblju od 2012. do 2017. godine, provedena je analiza trenda kretanja ozljeda na radu u Karlovačkoj županiji te dana usporedba sa stanjem u Republici Hrvatskoj u promatranom razdoblju od 6 godina.

\section{OSNOVNI POKAZATELJI DINAMIKE OZLJEDA NA RADU}

\section{Izračun osnovnih pokazatelja dinamike vremenskih pojava}

Pod vremenskim nizom $\left(y_{1}, y_{2}, \ldots, y_{n}\right)$ podrazumijeva se skup kronološko uređenih istovrsnih 
podataka (Biljan-August et al., 2009., Dumančić et al., 2011., Newbold et al., 2010., Vukičević, Papić, 2003.). Elementi tog skupa, vrijednosti $y_{t^{\prime}}$ $t=1,2, \ldots, n$, nazivaju se frekvencijama vremenskog niza, a broj članova niza $(n)$ predstavlja duljinu niza. Osnovnim pokazateljima dinamike vremenskih pojava opisuju se promjene razine pojava u promatranom razdoblju, i to:

- $\quad$ promjene u uzastopnim razdobljima i promjene u odnosu na neko bazno razdoblje,

- pojedinačne i prosječne promjene,

- apsolutne i relativne promjene.

Pojedinačna apsolutna promjena između dva uzastopna razdoblja dana je formulom:

$$
\Delta y_{t}=y_{t}-y_{t-1}, t=2,3, \ldots, n
$$

Pojedinačna apsolutna promjena u odnosu na neko bazno razdoblje $b$ računa se pomoću izraza:

$$
\Delta^{*} y_{t}=y_{t}-y_{b}, t=1,2, \ldots, n
$$

Pojedinačne relativne promjene ili koeficijenti dinamike za dva uzastopna (susjedna) razdoblja računaju se pomoću formule:

$$
K_{t}=\frac{\Delta y_{t}}{y_{t-1}}=\frac{y_{t}-y_{t-1}}{y_{t-1}}, t=2,3, \ldots, n
$$

Koeficijent dinamike pokazuje za koliko se relativno promijenila razina pojave u promatranom vremenu $t \mathrm{u}$ odnosu na prethodno vrijeme $t-1$.

Pojedinačna stopa promjene iz razdoblja u razdoblje $\left(S_{t}\right)$ pokazuje za koliko se u postotku promijenila razina pojave $\mathrm{u}$ vremenu $t \mathrm{u}$ odnosu na vrijeme $t-1$, a izračuna se iz izraza:

$$
S_{t}=K_{t} \cdot 100=\frac{\Delta y_{t}}{y_{t-1}} \cdot 100=\frac{y_{t}-y_{t-1}}{y_{t-1}} \cdot 100, t=2,3, \ldots, n \quad \text { [4] }
$$

Pojedinačna stopa promjene u odnosu na bazno razdoblje $\left(S_{t}^{*}\right)$ pokazuje za koliko se u postotku promijenila razina pojave $\mathrm{u}$ vremenu $t \mathrm{u}$ odnosu na bazno vrijeme $b$, a dobiva se izračunom pomoću formule:

$$
S_{t}^{*}=\frac{\Delta^{*} y_{t}}{y_{b}} \cdot 100=\frac{y_{t}-y_{b}}{y_{b}} \cdot 100, t=1,2, \ldots, n
$$

Prosječna stopa promjene izražava se u postotku, a definirana je formulom:

$$
\bar{S}=\left(\sqrt[n-1]{\frac{y_{n}}{y_{1}}}-1\right) \cdot 100
$$

\section{Rezultati izračuna osnovnih pokazatelja dinamike prijavljenih ozljeda na radu}

Izvor podataka za provedene statističke analize prijavljenih ozljeda na radu su godišnja izvješća Analiza ozljeda na radu u razdoblju od 2012. do 2017. godine koja su javno objavljena na internetskoj stranici HZZZSR-a (www.hzzzsr. hr). U Tablici 1 (za Karlovačku županiju) i Tablici 2 (za sve županije Republike Hrvatske) prikazani su evidentirani podaci od HZZZSR-a (3. stupac) te rezultati izračuna osnovnih pokazatelja dinamike promatranih vremenskih pojava (stupci 4 . - 8.) prema metodama opisanim u poglavlju Izračun osnovnih pokazatelja dinamike vremenskih pojava. Tablice su podijeljene u tri cjeline koje obrađuju:

- ukupan broj ozljeda na radu,

- broj ozljeda nastalih na mjestu rada,

- broj ozljeda nastalih na putu od/do mjesta rada.

Broj prijavljenih ozljeda na radu u Karlovačkoj županiji u razdoblju od 2012. do 2017. godine naveden je u 3. stupcu Tablice 1, i to odvojeno za: ukupan broj ozljeda na radu, broj ozljeda na mjestu rada i broj ozljeda na putu od/do mjesta rada u navedenom razdoblju. Rezultati izračuna su: pokazatelji pojedinačnih apsolutnih promjena između dva uzastopna razdoblja (4. stupac), pokazatelji pojedinačnih apsolutnih promjena u odnosu na 2012. godinu (5. stupac), koeficijenti dinamike (6. stupac), stope promjena (7. stupac) te pojedinačne stope u odnosu na 2012. godinu (8. stupac).

Iz rezultata predočenih u Tablici 1 može se zaključiti sljedeće:

- Najveća pojedinačna stopa promjene iz razdoblja u razdoblje, kod ukupnog broja ozljeda zabilježena je u 2017. godini kad 
je ukupan broj ozljeda bio veći 18,24 \% u odnosu na ukupan broj ozljeda u prethodnoj 2016. godini. Najveća stopa promjena $(-18,06 \%)$ ukupnog broja ozljeda na radu u odnosu na početnu 2012. godinu zabilježena je 2014. godine kada je apsolutna promjena u odnosu na 2012. godinu iznosila -69 (pad od 69 ukupno prijavljenih ozljeda).

- Najveća pojedinačna stopa promjene iz razdoblja u razdoblje, kod ozljeda na mjestu rada zabilježena je u 2015. godini kad je broj ozljeda na mjestu rada bio veći 20,87 \% u odnosu na broj tih ozljeda u prethodnoj 2014. godini. Najveća stopa promjena $(17,53 \%)$ broja ozljeda na mjestu radu u odnosu na početnu 2012. godinu zabilježena je u 2017. godini.

- Najveća pojedinačna stopa promjene iz razdoblja u razdoblje, kod broja ozljeda na putu zabilježena je u 2013. godini kad je broj ozljeda na putu bio manji 45,05 \% u odnosu na taj broj ozljeda u prethodnoj
2012. godini. U 2016. godini zabilježena je najveća stopa promjene $(-48,35 \%)$ broja ozljeda na putu u odnosu na početnu 2012. godinu (pad od 44 prijavljene ozljede na putu u odnosu na baznu godinu).

- Ako se promatra ukupni broj ozljeda na radu u proteklom razdoblju, tada je najmanji broj od 313 ozljeda zabilježen 2014. godine, a najveći broj od 402 ozljede zabilježen je 2017. godine i bio je veći za 18,24 \% u odnosu na 2012. godinu.

- Najmanji broj ozljeda na mjestu rada (254 ozljede) zabilježen je 2014. godine, a najveći od 342 ozljede zabilježen je 2017. godine i bio je veći za 17,53 \% u odnosu na 2012. godinu.

- Ako se promatra broj ozljeda na putu od/do mjesta rada u proteklom razdoblju, tada je najmanji broj od 47 ozljeda zabilježen 2016. godine i bio je manji za 48,35 \% u odnosu na 2012. godinu. Najveći broj od 91 ozljede zabilježen je 2012. godine. 
Tablica 1. Osnovni pokazatelji dinamike ozljeda na radu u Karlovačkoj županiji

Table 1. Basic dynamics indicators of occupational injuries in Karlovac County

\begin{tabular}{|c|c|c|c|c|c|c|c|}
\hline \multicolumn{8}{|c|}{ Karlovačka županija } \\
\hline Vrsta ozljede & Godina & Broj ozljeda & $\begin{array}{l}\text { Apsolutne } \\
\text { promjene }\end{array}$ & $\begin{array}{c}\text { Apsolutne } \\
\text { promjene u } \\
\text { odnosu na } 2012 \text {. }\end{array}$ & $\begin{array}{c}\text { Koeficijenti } \\
\text { dinamike }\end{array}$ & $\begin{array}{c}\text { Stope } \\
\text { promjene }\end{array}$ & $\begin{array}{l}\text { Pojedinačne stope } \\
\text { za } 2012 \text {. g. }\end{array}$ \\
\hline \multirow{6}{*}{$\begin{array}{l}\text { Ukupno } \\
\text { ozljeda na } \\
\text { radu }\end{array}$} & 2012. & 382 & & & & & \\
\hline & 2013. & 320 & -62 & -62 & $-0,162304$ & $-16,23 \%$ & $-16,23 \%$ \\
\hline & 2014. & 313 & -7 & -69 & $-0,021875$ & $-2,19 \%$ & $-18,06 \%$ \\
\hline & 2015. & 355 & 42 & -27 & 0,134185 & $13,42 \%$ & $-7,07 \%$ \\
\hline & 2016. & 340 & -15 & -42 & $-0,042254$ & $-4,23 \%$ & $-10,99 \%$ \\
\hline & 2017. & 402 & 62 & 20 & 0,182353 & $18,24 \%$ & $5,24 \%$ \\
\hline \multirow{6}{*}{$\begin{array}{l}\text { Ozljeda na } \\
\text { mjestu rada }\end{array}$} & 2012. & 291 & & & & & \\
\hline & 2013. & 270 & -21 & -21 & $-0,072165$ & $-7,22 \%$ & $-7,22 \%$ \\
\hline & 2014. & 254 & -16 & -37 & $-0,059259$ & $-5,93 \%$ & $-12,71 \%$ \\
\hline & 2015. & 307 & 53 & 16 & 0,208661 & $20,87 \%$ & $5,50 \%$ \\
\hline & 2016. & 293 & -14 & 2 & $-0,045603$ & $-4,56 \%$ & $0,69 \%$ \\
\hline & 2017. & 342 & 49 & 51 & 0,167235 & $16,72 \%$ & $17,53 \%$ \\
\hline \multirow{6}{*}{$\begin{array}{l}\text { Ozljeda na } \\
\text { putu od/do } \\
\text { mjesta rada }\end{array}$} & 2012. & 91 & & & & & \\
\hline & 2013. & 50 & -41 & -41 & $-0,450549$ & $-45,05 \%$ & $-45,05 \%$ \\
\hline & 2014. & 59 & 9 & -32 & 0,180000 & $18,00 \%$ & $-35,16 \%$ \\
\hline & 2015. & 48 & -11 & -43 & $-0,186441$ & $-18,64 \%$ & $-47,25 \%$ \\
\hline & 2016. & 47 & -1 & -44 & $-0,020833$ & $-2,08 \%$ & $-48,35 \%$ \\
\hline & 2017. & 60 & 13 & -31 & 0,276596 & $27,66 \%$ & $-34,07 \%$ \\
\hline
\end{tabular}

Izvor podataka (3. stupac): HZZZSR, Analiza ozljeda na radu (2012.-2017.), www.hzzzsr.hr

Obrada podataka: obrada autora metodama navedenim u poglavlju Izračun osnovnih pokazatelja dinamike vremenskih pojava 
Podaci o broju prijavljenih ozljeda na radu u Republici Hrvatskoj (uključene sve županije) dani su u 3. stupcu Tablice 2 iz koje se vidi: ukupan broj ozljeda na radu, broj ozljeda na mjestu rada i broj ozljeda na putu od/do mjesta rada u razdoblju od 2012. do 2017. godine. Tablica ujedno sa- drži i izračunate pokazatelje pojedinačnih apsolutnih promjena između dva uzastopna razdoblja (4. stupac), pojedinačnih apsolutnih promjena u odnosu na 2012. godinu (5. stupac), koeficijente dinamike (6. stupac), stope promjena (7. stupac) te pojedinačne stope za 2012. godinu (8. stupac).

Tablica 2. Osnovni pokazatelji dinamike ozljeda na radu u Republici Hrvatskoj

Table 2. Basic dynamics indicators of occupational injuries in the Republic of Croatia

\begin{tabular}{|c|c|c|c|c|c|c|c|}
\hline \multicolumn{8}{|c|}{ Republika Hrvatska } \\
\hline Vrsta ozljede & Godina & Broj ozljeda & $\begin{array}{l}\text { Apsolutne } \\
\text { promjene }\end{array}$ & $\begin{array}{c}\text { Apsolutne } \\
\text { promjene u } \\
\text { odnosu na } 2012 .\end{array}$ & $\begin{array}{l}\text { Koeficijenti } \\
\text { dinamike }\end{array}$ & $\begin{array}{c}\text { Stope } \\
\text { promjene }\end{array}$ & $\begin{array}{l}\text { Pojedinačne stope } \\
\text { za 2012. g. }\end{array}$ \\
\hline \multirow{6}{*}{$\begin{array}{l}\text { Ukupno } \\
\text { ozljeda na } \\
\text { radu u RH }\end{array}$} & 2012. & 14.076 & & & & & \\
\hline & 2013. & 13.796 & -280 & -280 & $-0,019892$ & $-1,99 \%$ & $-1,99 \%$ \\
\hline & 2014. & 13.929 & 133 & -147 & 0,009640 & $0,96 \%$ & $-1,04 \%$ \\
\hline & 2015. & 16.013 & 2.084 & 1.937 & 0,149616 & $14,96 \%$ & $13,76 \%$ \\
\hline & 2016. & 16.235 & 222 & 2.159 & 0,013864 & $1,39 \%$ & $15,34 \%$ \\
\hline & 2017. & 17.768 & 1.533 & 3.692 & 0,094426 & $9,44 \%$ & $26,23 \%$ \\
\hline \multirow{6}{*}{$\begin{array}{c}\text { Ozljeda na } \\
\text { mjestu rada } \\
\text { u RH }\end{array}$} & 2012. & 10.657 & & & & & \\
\hline & 2013. & 11.252 & 595 & 595 & 0,055832 & $5,58 \%$ & $5,58 \%$ \\
\hline & 2014. & 11.444 & 192 & 787 & 0,017064 & $1,71 \%$ & $7,38 \%$ \\
\hline & 2015. & 13.161 & 1.717 & 2.504 & 0,150035 & $15,00 \%$ & $23,50 \%$ \\
\hline & 2016. & 13.281 & 120 & 2.624 & 0,009118 & $0,91 \%$ & $24,62 \%$ \\
\hline & 2017. & 14.431 & 1.150 & 3.774 & 0,086590 & $8,66 \%$ & $35,41 \%$ \\
\hline \multirow{6}{*}{$\begin{array}{c}\text { Ozljeda na } \\
\text { putu od/do } \\
\text { mjesta rada } \\
\text { u RH }\end{array}$} & 2012. & 3.419 & & & & & \\
\hline & 2013. & 2.544 & -875 & -875 & $-0,255923$ & $-25,59 \%$ & $-25,59 \%$ \\
\hline & 2014. & 2.485 & -59 & -934 & $-0,023192$ & $-2,32 \%$ & $-27,32 \%$ \\
\hline & 2015. & 2.852 & 367 & -567 & 0,147686 & $14,77 \%$ & $-16,58 \%$ \\
\hline & 2016. & 2.954 & 102 & -465 & 0,035764 & $3,58 \%$ & $-13,60 \%$ \\
\hline & 2017. & 3.337 & 383 & -82 & 0,129655 & $12,97 \%$ & $-2,40 \%$ \\
\hline
\end{tabular}

Izvor podataka (3. stupac): HZZZSR, Analiza ozljeda na radu (2012.-2017.), www.hzzzsr.hr

Obrada podataka: obrada autora metodama navedenim u poglavlju Izračun osnovnih pokazatelja dinamike vremenskih pojava 
Iz rezultata predočenih u Tablici 2 može se zaključiti sljedeće:

- Najveća pojedinačna stopa promjene iz razdoblja u razdoblje, kod ukupnog broja ozljeda zabilježena je u 2015. godini kad je ukupan broj ozljeda bio veći 14,96 \% u odnosu na ukupan broj ozljeda u prethodnoj 2014. godini. Najveća stopa promjena $(26,23 \%)$ ukupnog broja ozljeda na radu u odnosu na početnu 2012. godinu zabilježena je 2017. godine kada je apsolutna promjena u odnosu na 2012. godinu iznosila 3.692 (više prijavljenih ozljeda).

- Najveća pojedinačna stopa promjene iz razdoblja u razdoblje, kod ozljeda na mjestu rada zabilježena je također u 2015. godini kad je broj ozljeda na mjestu rada bio veći $15 \%$ u odnosu na broj tih ozljeda u prethodnoj 2014. godini. Najveća stopa promjena $(35,41 \%)$ broja ozljeda na mjestu radu u odnosu na početnu 2012. godinu zabilježena je 2017. godine (3.774 više prijavljenih ozljeda na mjestu rada nego 2012. godine).

- Najveća pojedinačna stopa promjene iz razdoblja u razdoblje, kod broja ozljeda na putu od/do mjesta rada zabilježena je u 2013. godini kad je broj ozljeda na putu bio manji 25,59 \% u odnosu na taj broj ozljeda u prethodnoj 2012. godini. U 2014. godini zabilježena je najveća stopa promjene $(-27,32 \%)$ broja ozljeda na putu u odnosu na početnu 2012. godinu (pad od 934 prijavljene ozljede na putu u odnosu na baznu godinu).
- Ako se promatra ukupni broj ozljeda na radu u proteklom razdoblju, tada je najmanji broj od 13.796 ozljeda zabilježen 2013. godine, a najveći broj od 17.768 zabilježen je 2017. godine i bio je veći za 26,23\% u odnosu na 2012. godinu.

- Najmanji broj ozljeda na mjestu rada (10.657 ozljeda) zabilježen je 2012. godine, a najveći od 14.431 zabilježen je 2017. godine i bio je veći za 35,41 \% u odnosu na 2012. godinu.

- Ako se promatra broj ozljeda na putu u proteklom razdoblju, tada je najmanji broj od 2.485 ozljeda zabilježen 2014. godine i bio je manji za 27,32 \% u odnosu na 2012. godinu. Najveći broj od 3.419 ozljeda zabilježen je 2012. godine.

Prema podacima Državnog statističkog zavoda, broj zaposlenih osoba u Republici Hrvatskoj u razdoblju od 2012. do 2017. godine na godišnjoj razini do 2014. godine je padao, a od 2015. godine bilježi porast. Broj aktivnih osiguranika, kako u RH tako i u Karlovačkoj županiji, također ima trend pada do 2014. godine, a od 2015. godine taj broj raste (slike 1 i 2). Prema podacima HZZO-a, broj korištenih dana bolovanja na razini Republike Hrvatske ima identičan trend: sve do 2014. godine taj broj je bilježio pad, a od 2015. do 2017. godine rast (slika 3). U Karlovačkoj županiji, trend broja dana bolovanja ima slično ponašanje, iako zapravo ima trend laganog pada (slika 4). Svi ti podaci idu u prilog broju evidentiranih ozljeda na radu kako u RH tako i u Karlovačkoj županiji (stupac 5. i 8. Tablice 3).

Tablica 3. Podaci o broju zaposlenih, broju aktivnih osiguranika i broju dana bolovanja

Table 3. Data showing the numbers of employed persons, actively insured persons and sick days

\begin{tabular}{|c|c|c|c|c|c|c|c||}
\hline \hline Godina & $\begin{array}{c}\text { Broj } \\
\text { zaposlenih } \\
\text { u RH }\end{array}$ & $\begin{array}{c}\text { Broj } \\
\text { aktivnih } \\
\text { osiguranika } \\
\text { u RH }\end{array}$ & $\begin{array}{c}\text { Dani } \\
\text { bolovanja } \\
\text { u RH }\end{array}$ & $\begin{array}{c}\text { Ukupno } \\
\text { ozljeda na } \\
\text { radu u RH }\end{array}$ & $\begin{array}{c}\text { Broj aktivnih } \\
\text { osiguranika u } \\
\text { Karlovačkoj županiji }\end{array}$ & $\begin{array}{c}\text { Dani bolovanja } \\
\text { u Karlovačkoj } \\
\text { županiji }\end{array}$ & $\begin{array}{c}\text { Ukupno } \\
\text { ozljeda na radu } \\
\text { u Karlovačkoj } \\
\text { županiji }\end{array}$ \\
\hline 2012. & 1.395 .000 & 1.471 .662 & 14.315 .198 & 14.076 & 41.201 & 383.149 & 382 \\
\hline 2013. & 1.364 .000 & 1.455 .152 & 12.997 .567 & 13.796 & 40.978 & 332.335 & 320 \\
\hline 2014. & 1.342 .000 & 1.448 .737 & 12.518 .637 & 13.929 & 40.838 & 314.843 & 313 \\
\hline 2015. & 1.357 .000 & 1.466 .654 & 13.893 .980 & 16.013 & 41.206 & 342.797 & 355 \\
\hline 2016. & 1.390 .000 & 1.497 .178 & 14.391 .304 & 16.235 & 42.043 & 334.476 & 340 \\
\hline 2017. & 1.407 .000 & 1.522 .335 & 15.599 .777 & 17.768 & 42.701 & 374.684 & 402 \\
\hline
\end{tabular}

Izvor: DZS, www.dzs.hr (2. stupac), HZZO, www.hzzo,hr (3., 4., 6. i 7. stupac), HZZZSR, www.hzzzsr.hr (5. i 8. stupac) 




Slika 1. Aktivni osiguranici u RH

Figure 1. Actively insured persons in Croatia

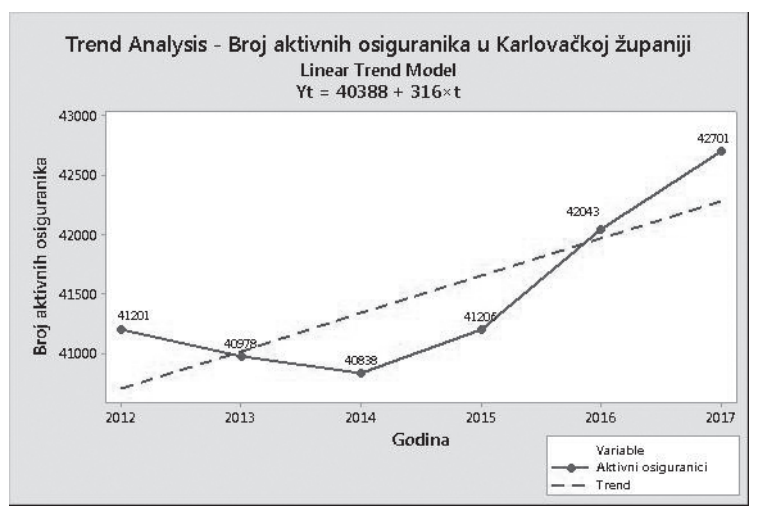

Slika 2. Aktivni osiguranici u Karlovačkoj županiji

Figure 2. Actively insured persons in Karlovac County

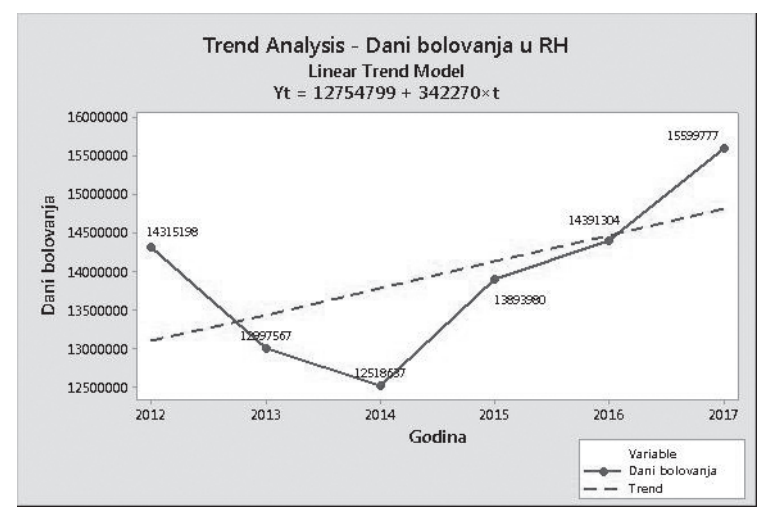

Slika 3. Dani bolovanja u RH

Figure 3. Number of sick days in Croatia

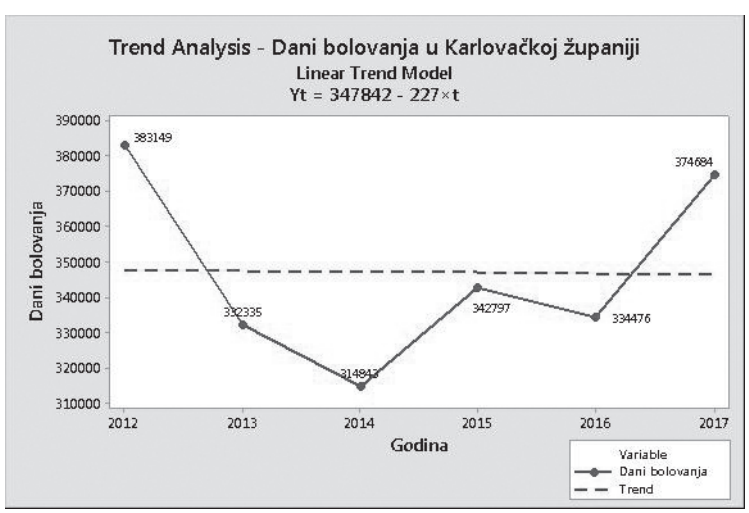

Slika 4. Dani bolovanja u Karlovačkoj županiji

Figure 4. Number of sick days in Karlovac County

\section{ANALIZA TRENDA KRETANJA OZLJEDA NA RADU}

\section{Linearni trend razvoja vremenskih pojava}

Ako postoji određena pravilnost u promjeni vrijednosti promatrane pojave u nekom razdoblju odnosno ako vremenski niz $\left(y_{t^{\prime}} t=1,2, \ldots, n\right)$ koji opisuje danu pojavu ima tendenciju pada ili rasta, tada se kaže da taj niz ima trend. Trend može biti linearan ili nelinearan, pozitivan (rast) ili negativan (pad) te različitih intenziteta $(B i-$ ljan-August et al., 2009., Newbold et al., 2010., Vukičević, Papić, 2003.).

U slučaju kad se promatrana pojava mijenja za približno iste apsolutne iznose u jednakim razdobljima, njezino se kretanje opisuje linearnim trendom. Model linearnog trenda odgovara modelu jednostavne linearne regresije u kojem je nezavisna varijabla $x$ vrijeme. Da bi se pojednostavio proračun i interpretacija rezultata, originalne vremenske jedinice (npr. godine) transformiraju se u varijablu $x_{t}$ koja poprima redom vrijednosti $0,1,2, \ldots, n-1$. Vrijednost 0 dodjeljuje se prvom članu niza (npr. prvoj godini), vrijednost 1 drugom članu (drugoj godini), itd. $U$ opisanom slučaju govori se o linearnom trendu s ishodištem na početku promatranog razdoblja. 
Jednadžba koja opisuje model linearnog trenda s ishodištem na početku promatranog razdoblja definirana je formulom (Tevčić et al., 2018.):

$$
\hat{y}=a_{0}+a_{1} x
$$

gdje su $a_{0}$ i $a_{1}$ parametri dani izrazima:

$$
\begin{gathered}
a_{1}=\frac{\sum_{t=1}^{n} x_{t} y_{t}-n \cdot \bar{x} \cdot \bar{y}}{\sum_{t=1}^{n} x_{t}^{2}-n \cdot \bar{x}^{2}} \\
a_{0}=\bar{y}-a_{1} \cdot \bar{x}
\end{gathered}
$$

Aritmetičke sredine frekvencija varijabli $x_{\mathrm{t}} \mathrm{i} y_{\mathrm{t}}$ računaju se pomoću izraza:

$$
\begin{aligned}
& \bar{x}=\frac{1}{n} \sum_{t=1}^{n} x_{t} \\
& \bar{y}=\frac{1}{n} \sum_{t=1}^{n} y_{t}
\end{aligned}
$$

Koeficijent $a_{1} u$ jednadžbi linearnog trenda [7] predstavlja prosječno smanjenje ili povećanje promatrane pojave u jedinici vremena, a koeficijent $a_{0}$ je prognozirana vrijednost (trend vrijednost) varijable $y \mathrm{u}$ ishodišnom razdoblju (vrijednost promatrane pojave za $x=0$ ). Trend vrijednosti $\hat{y}_{\mathrm{t}}$ određuju se tako da se u jednadžbu trenda $\hat{y}_{\mathrm{t}}=a_{0}+a_{1} x_{\mathrm{t}}$ uvrštavaju vrijednosti transformirane varijable $x_{\mathrm{t}}$ (vrijeme).

Reprezentativnost trenda procjenjuje se na temelju standardne devijacije trend modela te pripadajućeg koeficijenta varijacije:

$$
\begin{gathered}
\sigma_{\hat{y}}=\sqrt{\frac{\sum_{t=1}^{n}\left(y_{t}-\hat{y}_{t}\right)^{2}}{n}} \\
V_{\hat{y}}=\frac{\sigma_{\hat{y}}}{\bar{y}} \cdot 100
\end{gathered}
$$

\section{Linearni trend ozljeda na radu}

Primjenom modela linearnog trenda s ishodištem u 2012. godini provedeni su statistički izračuni trenda kretanja evidentiranih ozljeda na radu u Republici Hrvatskoj te posebno u Karlovačkoj županiji, i to u sve tri promatrane kategorije evidentiranih ozljeda na radu (ukupno, na mjestu rada, na putu od/do mjesta rada).

U Republici Hrvatskoj, pa tako i u Karlovačkoj županiji, iz godine u godinu, sve se više radi na edukaciji, boljem planiranju, kontroliranju te provođenju odgovarajućih mjera sigurnosti i zaštite na radu, pa je realno očekivati da je i broj prijavljenih ozljeda na radu svake godine manji. Međutim, gotovo suprotno, promatrajući podatke o broju evidentiranih ozljeda na radu u promatranom razdoblju od šest godina, može se primijetiti da je ukupan broj ozljeda na radu i broj ozljeda na mjestu rada imao trend rasta kako na razini Republike Hrvatske (slika 5) tako i u izdvojenoj Karlovačkoj županiji (slika 6). Na grafičkim prikazima trend modela uočljiv je pozitivan rast ukupnog broja evidentiranih ozljeda na radu (slike 7 i 8). Tendencija rasta pogotovo je izražena kod modela ozljeda na mjestu rada (slike 9 i 10). Najveći broj ozljeda na putu od/ do mjesta rada u Republici Hrvatskoj zabilježen je 2012. godine kad je iznosio 3.419 prijavljenih ozljeda. U 2013. godini taj broj je smanjen za $25,59 \%$, ali je nakon toga ponovno imao tendenciju blagog rasta (slika 11). U Karlovačkoj županiji najveći broj ozljeda na putu od/do mjesta rada zabilježen je 2012. godine (91 prijavljena ozljeda) i od tada u odnosu na tu baznu godinu konstantno pada. Jedini zabilježeni rast u odnosu na prethodnu godinu evidentiran je 2014. godine (18\% povećanje u odnosu na prethodnu 2013. godinu). Najmanji broj od 47 ozljeda na putu u Karlovačkoj županiji zabilježen je 2016. godine i bio je manji za 48,35\% u odnosu na 2012. godinu. Vremenski niz koji je predstavljen tim podacima ima negativan trend (slika 12). 
Tablica 4. Podaci o evidentiranim ozljedama na radu od 2012. do 2017. godine

Table 4. Registered data on occupational injuries, 2012-2017

\begin{tabular}{||c|c|c|c|c|c|c|}
\hline \multirow{2}{*}{ Godina } & \multicolumn{3}{|c|}{ Republika Hrvatska } & \multicolumn{3}{c|}{ Karlovačka županija } \\
\cline { 2 - 7 } & $\begin{array}{c}\text { Ukupno } \\
\text { ozljeda na radu }\end{array}$ & $\begin{array}{c}\text { Ozljeda na } \\
\text { mjestu rada }\end{array}$ & $\begin{array}{c}\text { Ozljeda na } \\
\text { putu }\end{array}$ & $\begin{array}{c}\text { Ukupno ozljeda } \\
\text { na radu }\end{array}$ & $\begin{array}{c}\text { Ozljeda na mjestu } \\
\text { rada }\end{array}$ & Ozljeda na putu \\
\hline 2012. & 14.076 & 10.657 & 3.419 & 382 & 291 & 91 \\
\hline 2013. & 13.796 & 11.252 & 2.544 & 320 & 270 & 50 \\
\hline 2014. & 13.929 & 11.444 & 2.485 & 313 & 254 & 48 \\
\hline 2015. & 16.013 & 13.161 & 2.852 & 355 & 307 & 47 \\
\hline 2016. & 16.235 & 13.281 & 2.954 & 340 & 293 & 342 \\
\hline 2017. & 17.768 & 14.431 & 3.337 & 402 & & 60 \\
\hline
\end{tabular}

Izvor podataka (3. stupac): HZZZSR, Analiza ozljeda na radu (2012.-2017., www.hzzzsr.hr

Karlovačka županija u odnosu na druge županije u Republici Hrvatskoj ima zabilježen relativno mali broj ozljeda na radu, ali taj je broj prvenstveno uvjetovan brojem aktivnih osiguranika prijavljenih na teret HZZO-a, a ne posebnim mjerama zaštite i sigurnosti na radu u toj županiji.

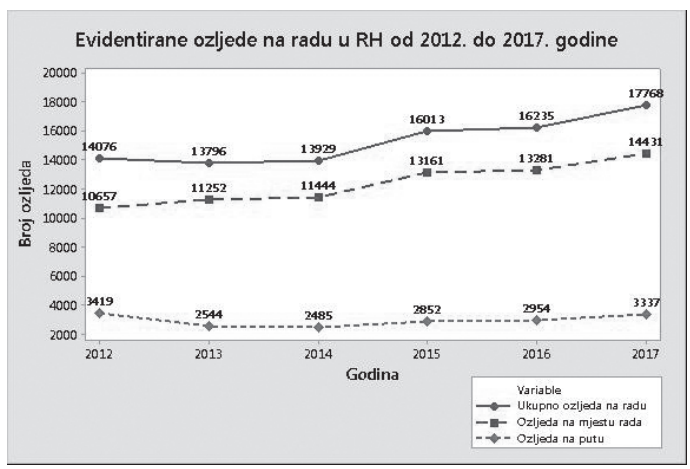

Slika 5. Ozljede na radu u $\mathrm{RH}^{1}$

Figure 5. Occupational injuries in the $R C$



Slika 6. Ozljede na radu u $K A^{2}$

Figure 6. Occupational injuries in $K A$

${ }^{1} \mathrm{RH}=$ Republika Hrvatska

${ }^{2} \mathrm{KA}=$ Karlovačka županija
Primjenom modela linearnog trenda $\mathrm{s}$ ishodištem u 2012. godini provedeni su statistički izračuni prognostičkog kretanja (trenda) evidentiranih ozljeda na radu. Rezultati izračuna te dobivene jednadžbe linearnog trenda provjerene su i programskom podrškom statističkog paketa Minitab u kojem su izrađeni svi grafički prikazi vremenskih nizova promatranih pojava i pripadajući trend modeli.

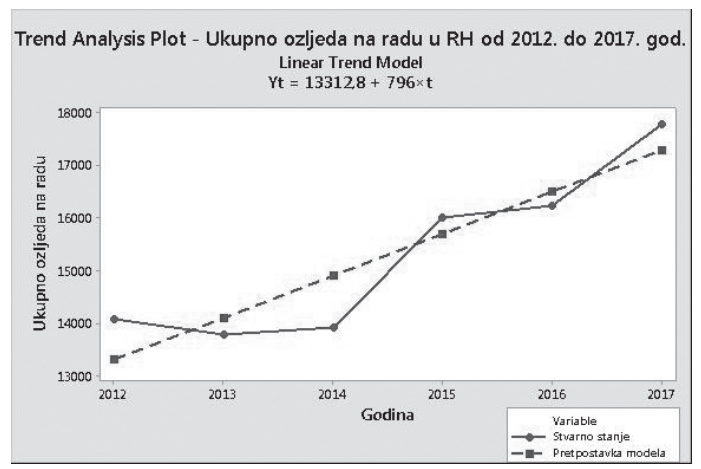

Slika 7. Trend - ukupno ozljeda u RH

Figure 7. Trend - total injuries in RC

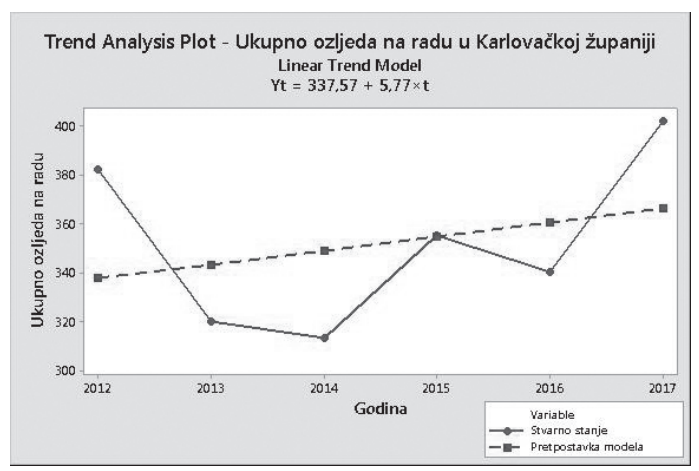

Slika 8. Trend - ukupno ozljeda u KA

Figure 8. Trend - total injuries in $K A$ 




Slika 9. Trend - ozljede na mjestu rada $u$ RH

Figure 9. Trend-injuries at workplace in the RC

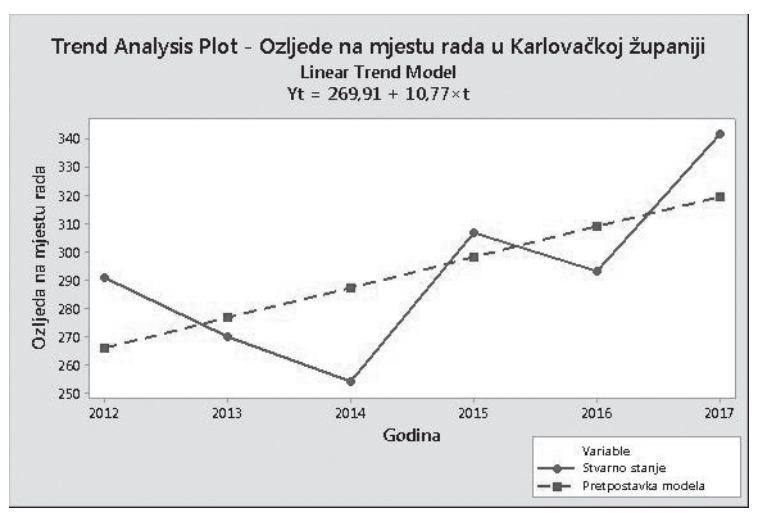

Slika 10. Trend - ozljede na mjestu rada u KA

Figure 10. Trend - injuries at workplace in $K A$

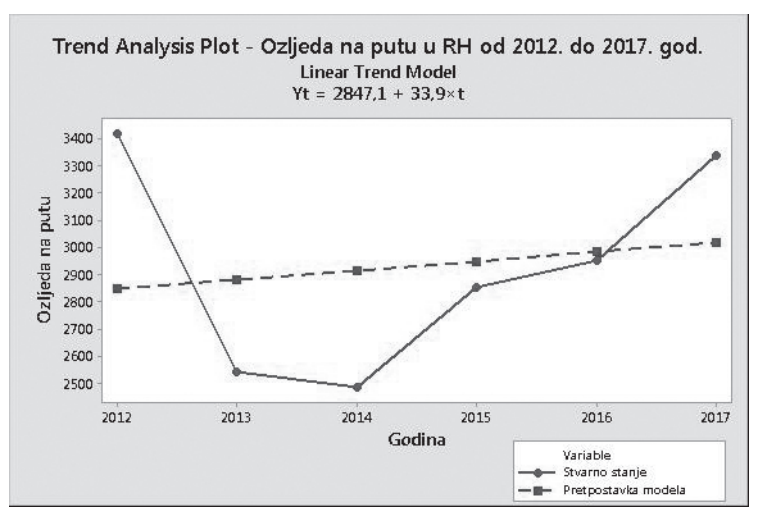

Slika 11. Trend - ozljede na putu u RH

Figure 11. Trend-commuting injuries in the RC



Slika 12. Trend - ozljede na putu u KA

Figure 12. Trend-commuting injuries in $K A$

Metodom opisanom u poglavlju Linearni trend razvoja vremenskih pojava dobivene su sljedeće jednadžbe linearnog trenda $\mathrm{s}$ ishodištem na početku promatranog razdoblja ( $x=0$ za 2012. godinu):

- $\hat{y}=13312,8+796 \cdot x$, ukupan broj ozljeda na radu u Republici Hrvatskoj,

- $\hat{y}=10465,7+762,1 \cdot x$, broj ozljeda na mjestu rada u Republici Hrvatskoj,

- $\hat{y}=2847,1+33,9 \cdot x$, broj ozljeda na putu od/do mjesta rada u Republici Hrvatskoj,

- $\hat{y}=337,57+5,77 \cdot x$, ukupan broj ozljeda na radu u Karlovačkoj županiji,

- $\hat{y}=269,91+10,77 \cdot x$, broj ozljeda na mjestu rada u Karlovačkoj županiji,

- $\hat{y}=71,67-5,00 \cdot x$, broj ozljeda na putu od/do mjesta rada u Karlovačkoj županiji.

Dobiveni prognostički (trend) modeli mogu se interpretirati na sljedeći način:

- ukupan broj ozljeda na radu u Republici Hrvatskoj u ishodišnoj (2012.) godini bio bi 13.313 ozljeda, a u promatranom razdoblju od 6 godina svake bi se godine $u$ prosjeku povećavao za 796 ozljeda,

- broj ozljeda na mjestu rada u Republici Hrvatskoj u početnoj 2012. godini bio bi 
10.466, a u promatranom razdoblju svake bi se godine u prosjeku povećavao za 762 ozljede,

- broj ozljeda na putu u Republici Hrvatskoj u ishodišnoj godini bio bi 2.847, a u promatranom razdoblju svake bi se godine u prosjeku povećavao za 34 ozljede,

- ukupan broj ozljeda na radu u Karlovačkoj županiji u ishodišnoj (2012.) godini bio bi 338, a u promatranom razdoblju svake bi se godine u prosjeku povećavao za 6 ozljeda,

- broj ozljeda na mjestu rada u Karlovačkoj županiji u ishodišnoj godini bio bi 270, a u promatranom razdoblju svake bi se godine u prosjeku povećao za 11,

- broj ozljeda na putu u Karlovačkoj županiji u ishodišnoj godini bio bi 72 ozljede, a u promatranom razdoblju svake bi se godine u prosjeku smanjivao za 5 ozljeda.

Ako se kretanje broja ozljeda nastavi po izračunatim prognostičkim modelima, u 2018. godini ( $x=6$ za 2018. godinu) može se očekivati:

- $\hat{y}=13312,8+796 \cdot 6=18.089$, ukupan broj ozljeda na radu u $\mathrm{RH}$,

- $\hat{y}=10465,7+762,1 \cdot 6=15.038$, broj ozljeda na mjestu rada u $\mathrm{RH}$,

- $\hat{y}=2847,1+33,9 \cdot 6=3.051$, broj ozljeda na putu u $\mathrm{RH}$,

- $\hat{y}=337,57+5,77 \cdot 6=372$, ukupan broj ozljeda na radu u Karlovačkoj županiji,

- $\hat{y}=269,91+10,77 \cdot 6=335$, broj ozljeda na mjestu rada u Karlovačkoj županiji,

- $\hat{y}=71,67-5,00 \cdot 6=42$, broj ozljeda na putu od/do mjesta rada u Karlovačkoj županiji.

Usporedbom podataka dobivenih izračunom prema prognostičkim modelima za 2018. godinu sa stvarnim (objavljenim) podacima za 2017. godinu može se zaključiti da će, ako se prognoze ostvare, u Republici Hrvatskoj u 2018. godini doći do blagog rasta ukupnog broja ozljeda na radu i broja ozljeda na mjestu rada te do blagog pada broja ozljeda na putu od/do mjesta rada u odnosu na 2017. godinu. S druge strane, ako se prognoze ostvare, u Karlovačkoj županiji doći će do smanjenja broja oz- ljeda u sve tri promatrane kategorije u odnosu na prethodnu (2017.) godinu.

Bez obzira na rezultate dobivene statističkim prognostičkim modelima, zabrinjava porast ukupnog broja ozljeda na radu te broja ozljeda na mjestu rada koji je u Republici Hrvatskoj zabilježen u 2017. godini u odnosu na prethodnu godinu (Tablica 2). U Karlovačkoj županiji iako je broj prijavljenih ozljeda na radu relativno malen, ipak je broj evidentiranih ozljeda u sve tri kategorije porastao u odnosu na prethodnu 2016. godinu (Tablica 1).

\section{ZAKLJUČAK}

Analizom službenih javno objavljenih podataka o broju prijavljenih ozljeda na radu u razdoblju od 2012. do 2017. godine utvrđen je trend kretanja godišnjeg broja ozljeda na radu u Republici Hrvatskoj te posebno u Karlovačkoj županiji. Objavljeni podaci i rezultati dobiveni statističkim metodama pokazuju da u promatranom razdoblju, kako na razini Republike Hrvatske tako i u Karlovačkoj županiji, u kategoriji ukupnog broja evidentiranih ozljeda na radu te ozljeda na mjestu rada postoji trend rasta broja ozljeda. Blagi trend pada uočen je jedino kod broja ozljeda na putu od/do mjesta rada u Karlovačkoj županiji, dok se na razini Republike Hrvatske očekuje blago povećanje broja ozljeda na putu. Utvrđeni trend porasta ukupnog godišnjeg broja ozljeda na radu i broja ozljeda na mjestu rada na razini čitave $\mathrm{RH}$ pokazatelj je kriznog stanja sigurnosti na radu u Republici Hrvatskoj te ukazuje na potrebu odgovornijeg planiranja, kontroliranja i provođenja odgovarajućih mjera sigurnosti i zaštite na radu. Svakodnevno, na svojim radnim mjestima djelatnici su izloženi raznim opasnostima i rizicima. Radnici, ali i poslodavci trebaju se držati mjera sigurnosti i zaštite zdravlja na mjestu rada, te svakodnevno raditi na njihovom unapređivanju.

\section{LITERATURA}

Biljan-August, M., Pivac, S., Štambuk, A.: Uporaba statistike u ekonomiji, Ekonomski fakultet Sveučilišta u Rijeci, Rijeka, 2009.

Državni zavod za statistiku (DZS): Statistički ljetopisi Republike Hrvatske (2012. - 2017.), dostupno na: www.dzs.hr, pristupljeno: 1.2.2019. 
Dumančić, K., Bahovec, V., Čižmešija, M., Kurtonoga-Živadinović, N.: Poslovna statistika, Element, Zagreb, 2011.

Hrvatski zavod za zaštitu zdravlja i sigurnosti na radu (HZZZSR): Analiza ozljeda na radu, dostupno na: na www.hzzzsr.hr, HZZZSR, Zagreb, 2012.2018., pristupljeno: 1.12.2018.

Hrvatski zavod za zdrastveno osiguranje (HZZO): Izvješće o poslovanju HZZO-a (2012. - 2017.), dostupno na: www.hzzo.hr, pristupljeno: 1.2.2019.

Newbold, P., Carlson, W.L., Thorne, B.: Statistika za poslovanje i ekonomiju, MATE d.o.o., Zagreb, 2010.

Pavlič, M., Markič, M.: Ozljede na radu u Republici Sloveniji od 1960. do 2008., Sigurnost, 52, 2010., 1, $1-17$.
Taradi, J.: Trend ozljeda na radu i profesionalnih bolesti kao ključni pokazatelj stanja sigurnosti na radu Hrvatskoj, Zbornik radova IV. znanstvenostručne konferencije "Menadžment i sigurnost", Čakovec, 2009.

Tevčić, M., Pavlović, B.: Trend ozljeda na radu u Republici Hrvatskoj od 2010. do 2017. godine, Book of Proceedings - 7th International Professional and Scientific Conference "OCCUPATIONAL SAFETY AND HEALTH", Veleučilište u Karlovcu, Karlovac, 2018.

Vukičević, M., Papić, M.: Matematičko-statistički priručnik za poduzetnike, Golden marketing-Tehnička knjiga, Zagreb, 2003.

Zakon o zaštiti na radu, N.N., br. 71/14., 118/14., 154/14., 94/18., 96/18.

\section{TRENDS IN WORK-RELATED INJURIES IN THE COUNTY OF KARLOVAC 2012 - 2017}

SUMMARY: One of the basic indicators of occupational safety development in a social environment in the observed period is the number of reported work-related injuries in a given period. The analysis of the published data on the number of registered work-related injuries for the period 2012-2017 identified development trends of the number of injuries in the Republic of Croatia. The anticipated developments in the number of injuries were analysed with special focus on the County of Karlovac. The identified increasing trend in work-related injuries on a yearly level points to a crisis in occupational safety, both in the County of Karlovac and in the Republic of Croatia, which highlights the need for more responsible planning, training, implementation and monitoring of occupational safety in all segments of society.

Key words: work-related injury, occupational safety, statistical methods, trend 